\title{
Water use efficiency of flooded rice fields II. Percolation and seepage losses
}

\author{
B.A.M. Bouman ${ }^{\text {a }}$ M.C.S. Wopereis ${ }^{\text {b,c,* }}$, M.J. Kropff ${ }^{\mathrm{c}}$, \\ H.F.M. ten Berge ${ }^{\mathrm{a}}$, T.P. Tuong ${ }^{\mathrm{c}}$ \\ ${ }^{a}$ DLO Centre for Agrobiological Research, P.O. Box 14,6700 AA Wageningen, The Netherlands \\ ${ }^{b}$ Department of Theoretical Production Ecology, Wageningen Agricultural University, P.O. Box 430, \\ 6700 AK Wageningen, The Netherlands \\ ${ }^{\mathrm{c}}$ International Rice Research Institute (IRRI), P.O. Box 933, 1099 Manila, Philippines
}

Accepted 12 April 1994

\begin{abstract}
The concept of a constant seepage and percolation (SP) rate in monitoring the water balance of flooded rice fields, as often used in e.g. irrigation system design and management, was investigated. First, magnitude and variability of percolation rate were studied for different combinations of soilhydraulic properties and hydrologic conditions using the validated water balance model SAWAH. Percolation losses from fields with relatively low subsoil permeability $\left(k_{\mathrm{s} \text {, sub }}<10^{-1} \mathrm{~cm} \mathrm{~d}^{-1}\right)$ are either limited by a poorly permeable plow sole $\left(k_{s, \text { top }}<10^{-2} \mathrm{~cm} \mathrm{~d} \mathrm{~d}^{-1}\right)$ or by the low hydraulic conductivity of the subsoil itself. Typical percolation losses of $0-0.5$ and $1-1.5 \mathrm{~cm} \cdot \mathrm{d}^{-1}$ respectively are hardly affected by ponded water depth, subsurface water content and depth of ground water table. Percolation losses from fields with relatively high subsoil permeability $\left(k_{\mathrm{s} \text {,sub }}>10^{1} \mathrm{~cm} \cdot \mathrm{d}^{-1}\right)$ may vary from $0-0.5 \mathrm{~cm} \mathrm{~d} d^{-1}$ with a poorly permeable plow sole, to $1-5 \mathrm{~cm} \cdot \mathrm{d}^{-1}$ or more for a relatively permeable plow sole $\left(k_{\mathrm{s} \text {, top }}>10^{-2} \mathrm{~cm} \mathrm{~d}^{-1}\right)$. Only in the latter case, percolation rates are largely affected by the depth of ponded water. Next, the constancy of combined SP rates was studied in a field experiment on a permeable subsoil. Simple book-keeping of the water balance using a fixed SP rate proved accurate to predict the depth of ponded water in time in case of a poorly permeable plow sole and a small seepage component. A decision tree was suggested based on soil-hydraulic properties and characteristics of bunds to estimate the magnitude and variation of SP rates, and to decide whether book-keeping with a fixed SP rate is an appropriate tool in monitoring the water balance of paddy fields.
\end{abstract}

Keywords: Rice; Water use efficiency; Simulation modelling

* Corresponding author. West Africa Rice Development Association (WARDA/ADRAO), B.P. 96, St. Louis, Senegal. 


\section{Introduction}

Keeping track of the soil-water balance of irrigated rice is an essential element in the design and operation of irrigation systems. Often simple book-keeping methods are used that specify gain and loss of water over a specified depth, such as the root zone (e.g. FAO, 1984):

$$
d W=I+R-E T_{\mathrm{c}}-S-P-D
$$

where $d W=$ change in ponded water depth $\left(\mathrm{cm} \cdot \mathrm{d}^{-1}\right), I=$ irrigation $\left(\mathrm{cm} \cdot \mathrm{d}^{-1}\right), R=$ rainfall $\left(\mathrm{cm} \cdot \mathrm{d}^{-1}\right), \mathrm{ET}_{\mathrm{c}}=$ evapotranspiration of the $\operatorname{crop}\left(\mathrm{cm} \cdot \mathrm{d}^{-1}\right), S=$ seepage $\left(\mathrm{cm} \cdot \mathrm{d}^{-1}\right)$, $P=$ percolation $\left(\mathrm{cm} \cdot \mathrm{d}^{-1}\right)$ and $D=$ bund overflow $\left(\mathrm{cm} \mathrm{d}^{-1}\right)$.

Rainfall is measured at meteorological stations. Irrigation I is usually applied when the depth of ponded water $\mathrm{dW}$ has reached a critical (minimum) level. Evapotranspiration of the crop can be computed according to FAO guidelines (FAO, 1984):

$$
\mathrm{ET}_{\mathrm{c}}=\mathrm{ET}_{0} \cdot K_{\mathrm{c}}
$$

where $\mathrm{ET}_{0}$ is reference crop evapotranspiration, and $K_{\mathrm{c}}$ is a crop coefficient. $\mathrm{ET}_{0}$ can be calculated (e.g. Penman, 1948, or Blaney-Criddle, 1950), or derived from measured pan evaporation. Crop coefficients for paddy rice are given by FAO (1984).

Seepage and percolation rates are difficult to measure separately in the field and are usually combined in one loss term, SP (see for review Wickham and Singh, 1978). Fieldaverage SP rates can simply be measured by sloping gauges placed in the field. The measured values are an integrated result of vertical percolation loss and in- and out-going lateral water flow (seepage) to and from neighbouring fields, respectively. Seepage and percolation losses are a key-element in the water use efficiency of rice (see Part I of this paper; Wopereis et al., 1994b), and the constancy of the measured SP rate in time determines the accuracy - or degree of success - of simple book-keeping methods for the soil-water balance [Eq. (1) ]. Seepage and percolation rates are affected by a range of soil physical and hydraulic properties, like structure, texture, conductivity, and by the hydrological environment, e.g. subsoil moisture content, ground water table depth, ponded water depth, field location, and condition of the bunds (Wickham and Singh, 1978; Angus and Zandstra, 1980). Relationships between SP rates and these factors have mainly been derived empirically. Soil-water balance models are in principle suitable to relate components of the water balance, such as SP rate, to soil hydraulic characteristics. So far, most soil water balance models are onedimensional (e.g. Driessen, 1986; ten Berge et al., 1992) and do not include lateral seepage through and underneath bunds. However, such models are useful to make a start in analyzing the relationship between percolation rate and soil physical and hydraulic properties, in addition to field observations.

In this paper, the magnitude and stability of SP rates of paddy fields is investigated. First, the one-dimensional soil water balance model SAWAH (Simulation Algorithm for Water flow in Aquic Habitats), validated for paddy soils in Part I of this paper (Wopereis et al., $1994 \mathrm{~b}$ ), is used to quantify the effects of soil physical and hydraulic properties on percolation rate only. The constancy of percolation rate is studied in relation to changes in 
hydrology, i.e. subsurface moisture content, ground water table depth and ponded water depth. Different combinations of soil properties are explored to arrive at classification rules that distinguish classes of soil properties with similar behaviour, i.e. magnitude and constancy, in percolation rate. In a next step, seepage is taken into account by studying combined SP rates in a field experiment at IRRI, described in Part I of this paper (Wopereis et al., 1994b). A simple book-keeping water balance model is used to simulate fluctuations of ponded water depth in the experiment and results are compared with those derived using the SAWAH model. A decision tree is suggested based on soil-hydraulic properties and bund characteristics to indicate the magnitude and/or stability of SP rates in field situations, and to decide whether book-keeping with a fixed SP rate is an appropriate tool in tracking the water balance of paddy fields.

\section{Materials and methods}

The soil-water balance model SAWAH (see Part I of this paper, Wopereis et al., 1994b) was used to study the effect of the following soil physical and hydraulic properties on percolation rates in flooded, puddled rice fields:

- saturated hydraulic conductivity of the plow sole $\left(k_{\mathrm{s}, \text { top }}\right)$

- thickness of the plow sole $\left(D_{z}\right)$

- depth of the ponded water layer plus muddy layer $\left(Z_{\mathrm{p}}\right)$

- hydraulic conductivity of the subsoil $\left(k_{\mathrm{s}, \mathrm{sub}}\right)$

- initial moisture content of the subsoil/pressure head of the subsoil

- water table depth

Stratification of the puddled topsoil in a "muddy layer" and a plow sole is discussed in Part I of this paper (Wopereis et al., 1994b).

Four simulation series were carried out (Table 1). In the first three series, the pressure head at the top of the plow sole was kept at $30 \mathrm{~cm}$, composed of $10 \mathrm{~cm}$ ponded water and $20 \mathrm{~cm}$ muddy layer. The daily percolation rate $P$ was simulated until a steady state was reached $(d P / P<1 \%)$. In the fourth simulation series, a water layer of $15 \mathrm{~cm}$ on top of a $15 \mathrm{~cm}$ muddy layer was left to infiltrate through the plow sole during 45 days.

Table 1

Hydraulic properties of the plow sole and of the non-puddled subsoil in the four simulation series

\begin{tabular}{|c|c|c|c|c|c|c|}
\hline \multirow[t]{2}{*}{ Series } & \multicolumn{2}{|c|}{ Puddled topsoil } & \multicolumn{3}{|c|}{ Non-puddled subsoil } & \multirow[t]{2}{*}{ WT depth } \\
\hline & $D_{\mathrm{z}}$ & $k_{\mathrm{s}, \mathrm{top}}$ & Text & $k_{\mathrm{s}, \text { sub }}$ & IMC & \\
\hline 1 & 5 & $0.3,0.03$ & $\mathrm{HC}$ & 0.22 & $18,36,49$ & 110 \\
\hline 2 & $10,5,2$ & 0.3 & $\mathrm{SiC}$ & 1.3 & $11,20,30,45$ & 110 \\
\hline 3 & 5 & 0.3 & $\mathrm{SiC}$ & 1.3 & 20 & $500,200,110,50,20$ \\
\hline \multirow[t]{2}{*}{4} & 5 & $0.3,0.03$ & SL & 16.5 & 1,27 & $500,200,110,50,20$ \\
\hline & 5 & $0.3,0.03$ & $\mathrm{SiC}$ & 1.3 & 11,45 & $500,200,110,50,20$ \\
\hline
\end{tabular}

$D_{\mathrm{z}}=$ thickness plow sole in $\mathrm{cm}, k_{\mathrm{s}, \text { top }}=$ hydralic conductivity of plow sole in $\mathrm{cm} \cdot \mathrm{d}^{-1}, k_{\mathrm{s}, \mathrm{sub}}=$ hydraulic conductivity subsoil in $\mathrm{cm} \cdot \mathrm{d}^{-1} ; \mathrm{IMC}=$ initial volumetric moisture content $(\%)$, WT depth $=$ water table depth below top of plow sole $(\mathrm{cm}) ; \mathrm{Text}=$ texture $\mathrm{HC}=$ heavy clay; $\mathrm{SiC}=$ silty clay; $\mathrm{SL}=$ sandy loam. 
The hydraulic conductivity of the plow sole was varied between $0.03 \mathrm{~cm} \cdot \mathrm{d}^{-1}$ for a wellpuddled soil, a value reported by Wopereis et al. (1992), and $0.3 \mathrm{~cm} \cdot \mathrm{d}^{-1}$ for a poorly puddled soil. Hyraulic conductivity data for the subsoil were taken from Penning de Vries et al. (1989).

The validity of using a stable, field-average SP rate in book-keeping of the water balance [Eq. (1) ], was tested using the field experiment described in Part I of this paper (Wopereis et al., 1994b). In this experiment, combined SP rates were measured with sloping gauges installed in the field. The water losses calculated from the sloping gauge readings were corrected for evapotranspiration as measured by daily weighing of pots with and without rice plants placed in the field. The resulting SP rates quantify the total seepage and percolation loss on a field basis. Simple book-keeping of the water balance [Eq. (1)], was used to simulate fluctuations of ponded water depth over time.

\section{Results}

\subsection{Simulation series 1: impact of $k_{s, t o p}$ and $k_{s, s u b}$}

The hydraulic resistance of a $5 \mathrm{~cm}$, poorly permeable plow sole $\left(k_{\mathrm{s}, \text { top }}=0.03 \mathrm{~cm} \cdot \mathrm{d}^{-1}\right)$ was relatively large (Fig. 1). Only a small amount of water percolated through the plow sole which was easily transported downward. The water content in the subsoil did not affect percolation rate and the steady-state percolation was reached during the first day of simulation.

The hydraulic conductivity of the heavy clay subsoil, $k_{\mathrm{s}, \mathrm{sub}}$, became limiting to percolation in case of a relatively permeable plow sole $\left(k_{\mathrm{s}, \mathrm{top}}=0.3 \mathrm{~cm} \mathrm{~d}^{-1}\right)$. The initial high percolation rates through the plow sole could not be drained to the water table. The subsoil gradually filled up with water and the pressure head $h_{\text {sub }}$ (immediately) below the plow sole increased

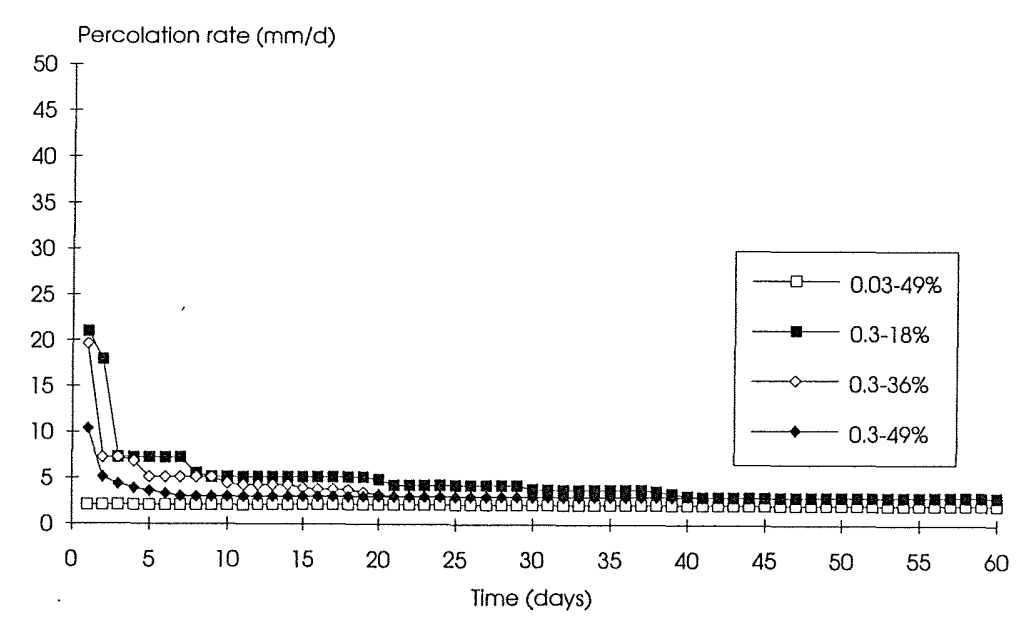

Fig. 1. Simulated percolation rates for different combinations of $k_{\mathrm{s}, \mathrm{top}}\left(0.03\right.$ or $\left.0.3 \mathrm{~cm} \cdot \mathrm{d}^{-1}\right)$ and initial subsoil water content $(18,36$ or 49 vol.\%) for a heavy clay subsoil. See text and Table 1 (series 1 ) for further details. 
(Fig. 2a,b). With decreasing suction in the subsoil below the plow sole, percolation decreased until a steady state and saturation of the subsoil was reached. It can be shown that for $k_{\mathrm{s} \text {,top }} \cdot\left(Z_{\mathrm{p}}+D_{\mathrm{z}}\right) / D_{\mathrm{z}}>k_{\mathrm{s} \text {, sub }}$, astate is only reached if the saturated Part of the subsoil reaches the water table. During the percolation process, the subsoil also filled up from below due to capillary rise (Fig. 2a).

\subsection{Simulation series 2: impact of thickness of the plow sole}

Resistance to water flow was relatively high for a relatively permeable plow sole $\left(k_{\mathrm{s}}\right.$, top $=0.3 \mathrm{~cm} \mathrm{~d}^{-1}$ ) if the thickness of this layer was $10 \mathrm{~cm}$ (Fig. 3a). Percolation rates were still quite high $\left(1.27 \mathrm{~cm} \mathrm{~d}^{-1}\right)$ and were hardly affected by the pressure head $h_{\text {sub }}$ in the subsoil below the plow sole.

With a $5 \mathrm{~cm}$ plow sole, the initial percolation rate was about twice as high as with a 10 $\mathrm{cm}$ plow sole (Fig. $3 \mathrm{~b}$ ). The resulting amount of percolating water was greater than the subsoil's drainage capability, i.e. greater than the vertical flux through the subsoil. The water content in the subsoil below the plow sole subsequently increased, which increased the pressure head $h_{\text {sub }}$ and further reduced water flow through the plow sole. A steady state was reached sooner with a higher initial water content.

With a $2 \mathrm{~cm}$ plow sole (Fig. 3c), initial percolation rates were even higher than in case of a $5 \mathrm{~cm}$ plow sole. The subsoil filled up quickly after which a steady state was reached.

\subsection{Simulation series 3: impact of water table depth}

Percolation rates the conductivity of the subsoil because of the high hydraulic conductivity of the plow sole. A shallower water table reduced the thickness of the zone between the plow sole and the water table. As a result, percolating water filled up the subsoil faster and a steady-state was reached sooner (Fig. 4). Rates of steady-state percolation increased because the hydraulic head gradient in the saturated subsoil layer increased as the thickness of this layer decreased. This effect became more pronounced with shallower water tables as the relative contribution of the puddled layer to the resistance of the saturated subsoil section increased. The steady-state percolation rate increased from $1.51 \mathrm{~cm} \cdot \mathrm{d}^{-1}$ to 1.58 $\mathrm{cm} \cdot \mathrm{d}^{-1}$ if the water table depth was varied from 500 to $50 \mathrm{~cm}$. If the water table was raised further, to $20 \mathrm{~cm}$ below the top of the plow sole, percolation rate increased to $1.85 \mathrm{~cm} \cdot \mathrm{d}^{-1}$. It should be remembered here that the water table is a boundary condition in SAWAH. Percolating soil water that reaches the water table is assumed to flow away laterally. It does not lead to a rise of the water table.

\subsection{Simulation series 4: impact of depth of ponded water and muddy suspension}

A poorly permeable plow sole $\left(k_{\mathrm{s}, \text { top }}=0.03 \mathrm{~cm} \mathrm{~d}^{-1}\right)$ determined percolation rates regardless of the type of subsoil, its initial water content or water table depth (line 1, Fig. 5a). The low percolation rate was a linear function of pressure head $h_{\text {top }}$ (depth of ponded water + muddy suspension) at the top of the plow sole, though the variation was very small in absolute sense. The same phenomenon was found for a relatively permeable plow sole 
(a) Depth (cm)

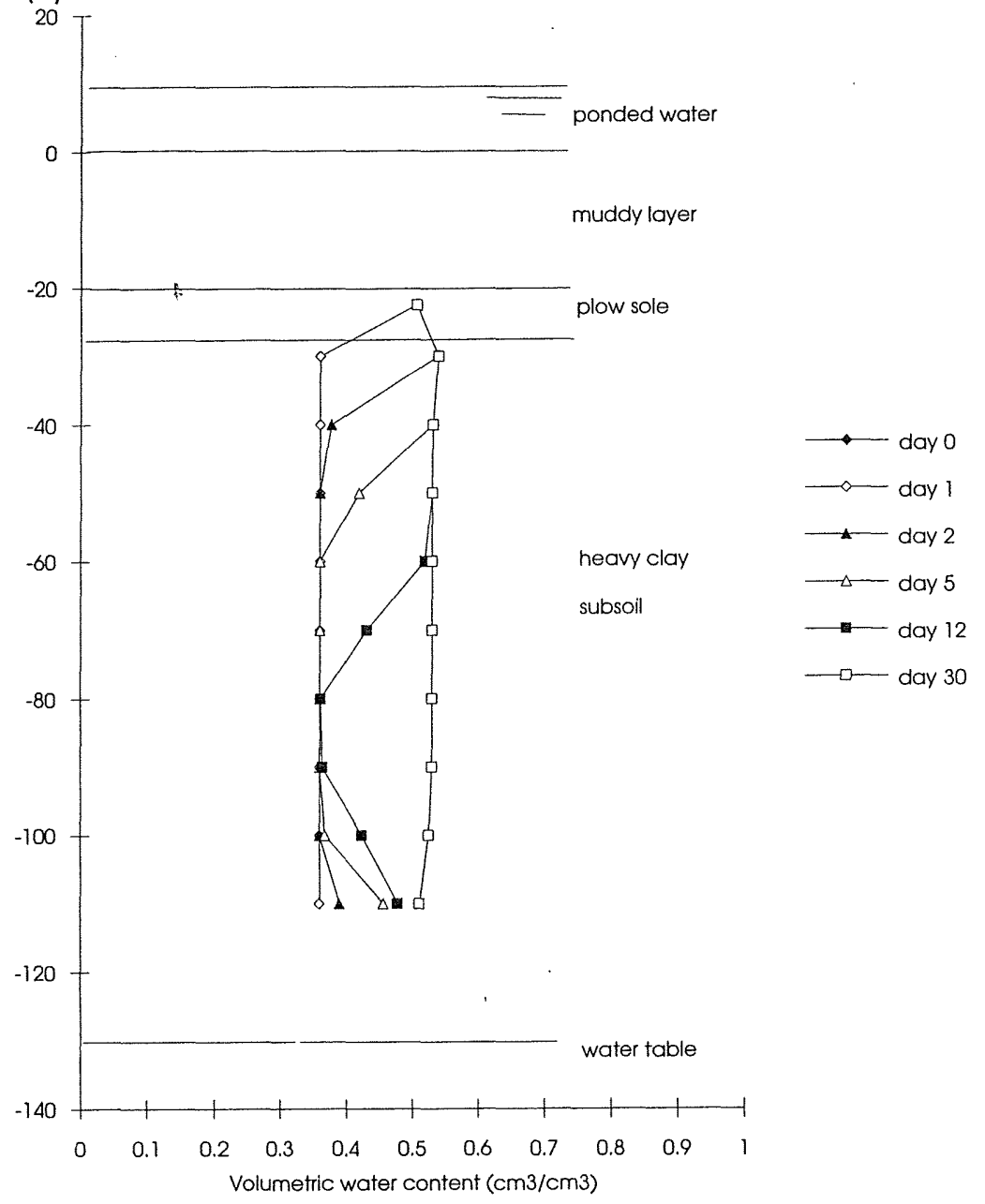

$\left(k_{\mathrm{s} \text {,top }}=0.3 \mathrm{~cm} \mathrm{~d}^{-1}\right)$ overlying a relatively permeable subsoil (sandy loam) but the percolation rate was much higher (line 2, Fig. 5a).

Percolation rates in case of a relatively permeable plow sole overlying a poorly permeable subsoil ( silty clay), were mainly determined by the pressure head $h_{\text {sub }}$ in the subsoil below the plow sole (Fig. 5b). If the subsoil was initially dry, the low pressure head resulted in rapid absorption of percolating water. The same relationship with depth of ponded water was observed as in Fig. 5a. However, with increasing water content of the subsoil below the plow sole the increasing pressure head reduced vertical water flow and limited percolation rates. The steady-state percolation rate was again a linear function of depth of ponded water. The slope of the line in Fig. 5b is smaller than that of line 2 in Fig. 5a because the percolation rate is determined by the difference in pressure head over the whole saturated section ( = plow sole + saturated subsoil) divided by the thickness of the saturated section. 


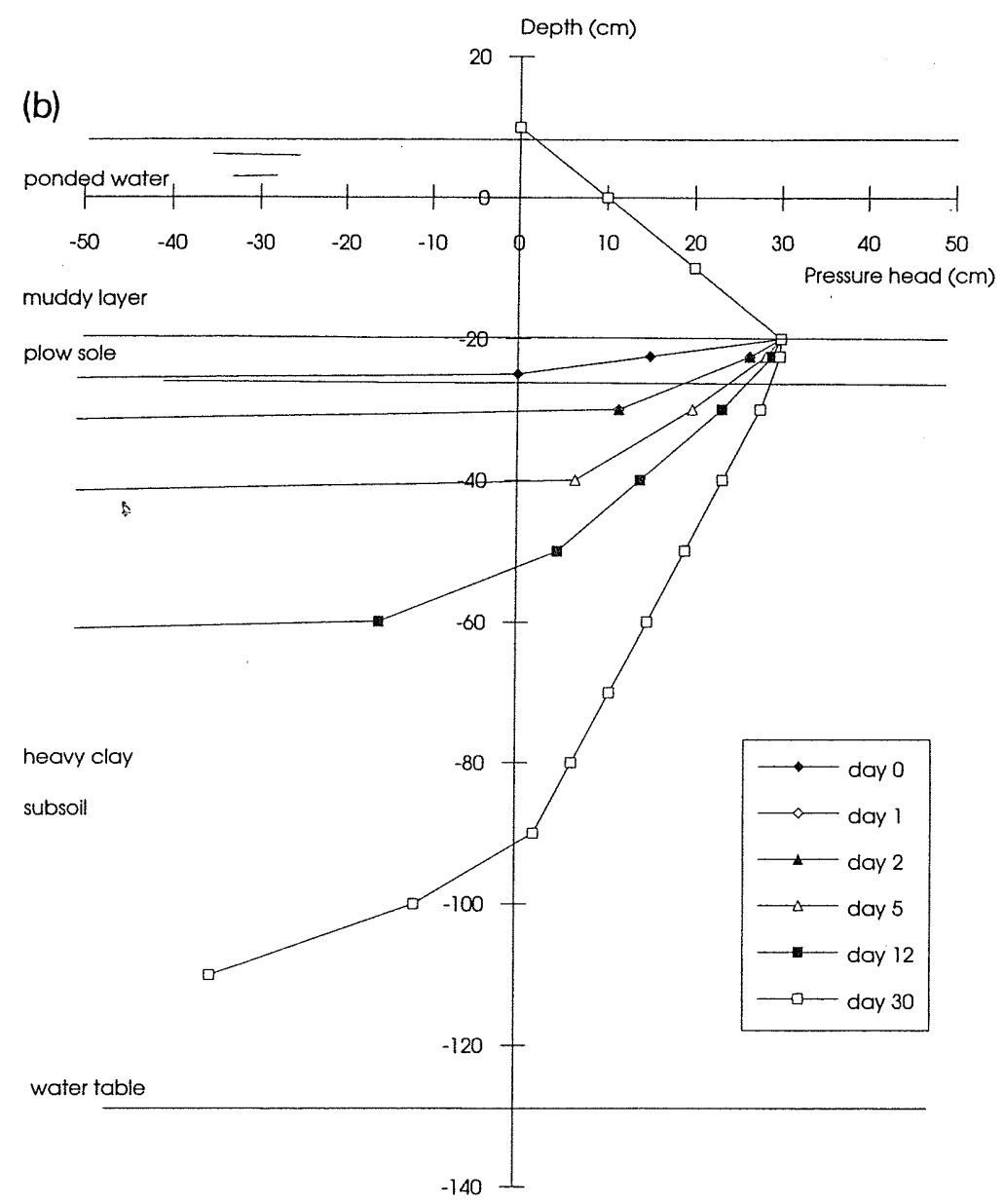

Fig. 2. Changes in water content (a) and pressure head $h_{\text {sub }}$ (b) in the subsoil due to infiltrating water at various days after the start of simulation. The subsoil is of heavy clay texture and has an initial water content of 36 vol. $\%$; $k_{\mathrm{s}, \text { top }}(5 \mathrm{~cm}$ plow sole $)=0.3 \mathrm{~cm} \cdot \mathrm{d}^{-1}$.

In Fig. 5a it is determined by the difference in pressure head divided by the thickness of the plow sole only.

A change in water table depth from 500 to $50 \mathrm{~cm}$ had not much effect on percolation rate. With a water table depth of $20 \mathrm{~cm}$, the steady state was reached two days after the start of simulation and percolation rate was high.

\subsection{Soil-hydraulic classes}

The physical and hydraulic characteristics of the plow sole and of the underlying subsoil determined magnitude and constancy of percolation rate. Four soil-hydraulic classes can be distinguished: 

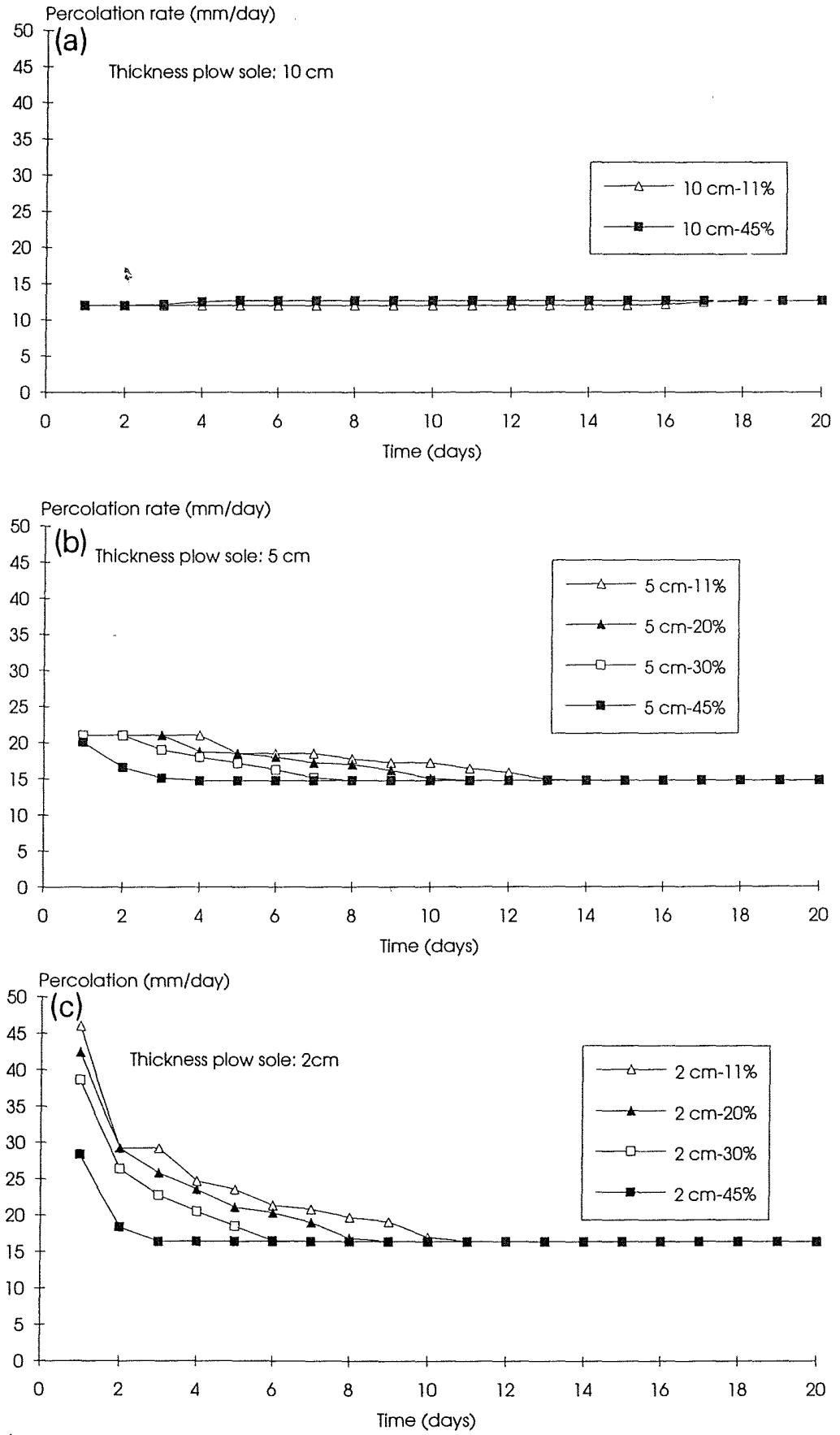

Fig. 3. Changes in percolation rate for plow sole of $10 \mathrm{~cm}(\mathrm{a}), 5 \mathrm{~cm}$ (b) and $2 \mathrm{~cm}(\mathrm{c})$. The legend refers to the initial water content of the silty clay subsoil. See text and Table 1 (series 2 ) for further details. 


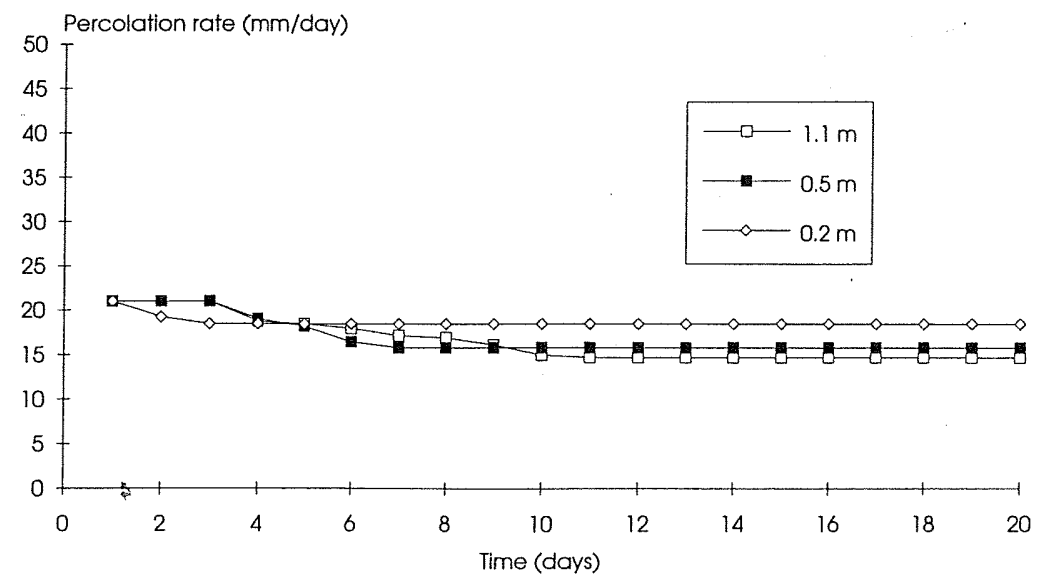

Fig. 4. Changes in percolation rate at varying depths of the water table $(5.0,2.0,1.1,0.5$ and $0.2 \mathrm{~m}$ depth) in a silty clay subsoil. Further details are given in the text and in Table 1 (series 3 ).

- Ia Poorly permeable plow sole (low $k_{\mathrm{s}, \text { top }}$ ) - poorly permeable subsoil (low $k_{\mathrm{s}, \mathrm{sub}}$ )

- Ib Poorly permeable plow sole (low $k_{\mathrm{s}, \text { top }}$ ) - permeable subsoil (high $k_{\mathrm{s}, \mathrm{sub}}$ )

- IIa Permeable plow sole (high $k_{\mathrm{s}, \mathrm{top}}$ ) - poorly permeable subsoil (low $k_{\mathrm{s}, \mathrm{sub}}$ )

- IIb Permeable plow sole (high $k_{\mathrm{s}, \text { top }}$ ) - permeable subsoil (high $k_{\mathrm{s}, \mathrm{sub}}$ )

$I a$ and $I b$. In well-puddled soils with a poorly permeable plow sole $\left(k_{\mathrm{s}, \text { top }}\right.$ in the order of $10^{-2} \mathrm{~cm} /$ day or less; thickness $D_{\mathrm{z}}$ in the order of $5 \mathrm{~cm}$ or more), percolation rate is about $0.2-0.5 \mathrm{~cm} \cdot \mathrm{d}^{-1}$, linearly related to depth of ponded water and independent from the hydraulic characteristics and water status of the subsoil. The variation of percolation rate with ponded water depth, however, is small.

IIa. Percolation rates are limited by the hydraulic conductivity of the subsoil in case of a poorly puddled topsoil (e.g. a thin plow sole $D_{\mathrm{z}}<5 \mathrm{~cm}$, or $k_{\mathrm{s} \text {,top }}$ in the order of $10^{-1} \mathrm{~cm}$ $\mathrm{d}^{-1}$ or more) overlying a poorly permeable subsoil $\left(k_{\mathrm{s} \text { sub }}\right.$ in the order of $10^{-1} \mathrm{~cm} \mathrm{~d}^{-1}$ or less). Initial percolation rates can be high, especially if the subsoil is dry, but will gradually decrease, until a steady-state is reached after 1-3 weeks. The time needed to reach steadystate is influenced by the initial water content of the subsoil and the water table depth. In practice, the soil profile will often be brought near field capacity during land preparation, and percolation rates will often be already at steady-state after puddling. The steady-state percolation rate is a linear function of the depth of ponded water, but the variation of percolation rate with depth of ponded water depth is small.

$I I b$. Percolation rate for a less-effectively puddled topsoil overlying a relatively permeable subsoil $\left(k_{\mathrm{s}, \mathrm{sub}}\right.$ in the order of $10^{1} \mathrm{~cm} \cdot \mathrm{d}^{-1}$ and larger), is again determined by the hydraulic characteristics of the plow sole only. Percolation rates are $1.0-2.5 \mathrm{~cm} \cdot \mathrm{d}^{-1}$ (or higher) and linearly related to ponded water depth. Variation of percolation rate with ponded water depth is relatively large.

\subsection{Field experiment}

The field experiment consisted of four stages; see Part I of this paper (Wopereis et al., 1994b). Stages 1 and 2 had a homogeneous, poorly permeable plow sole with a low 

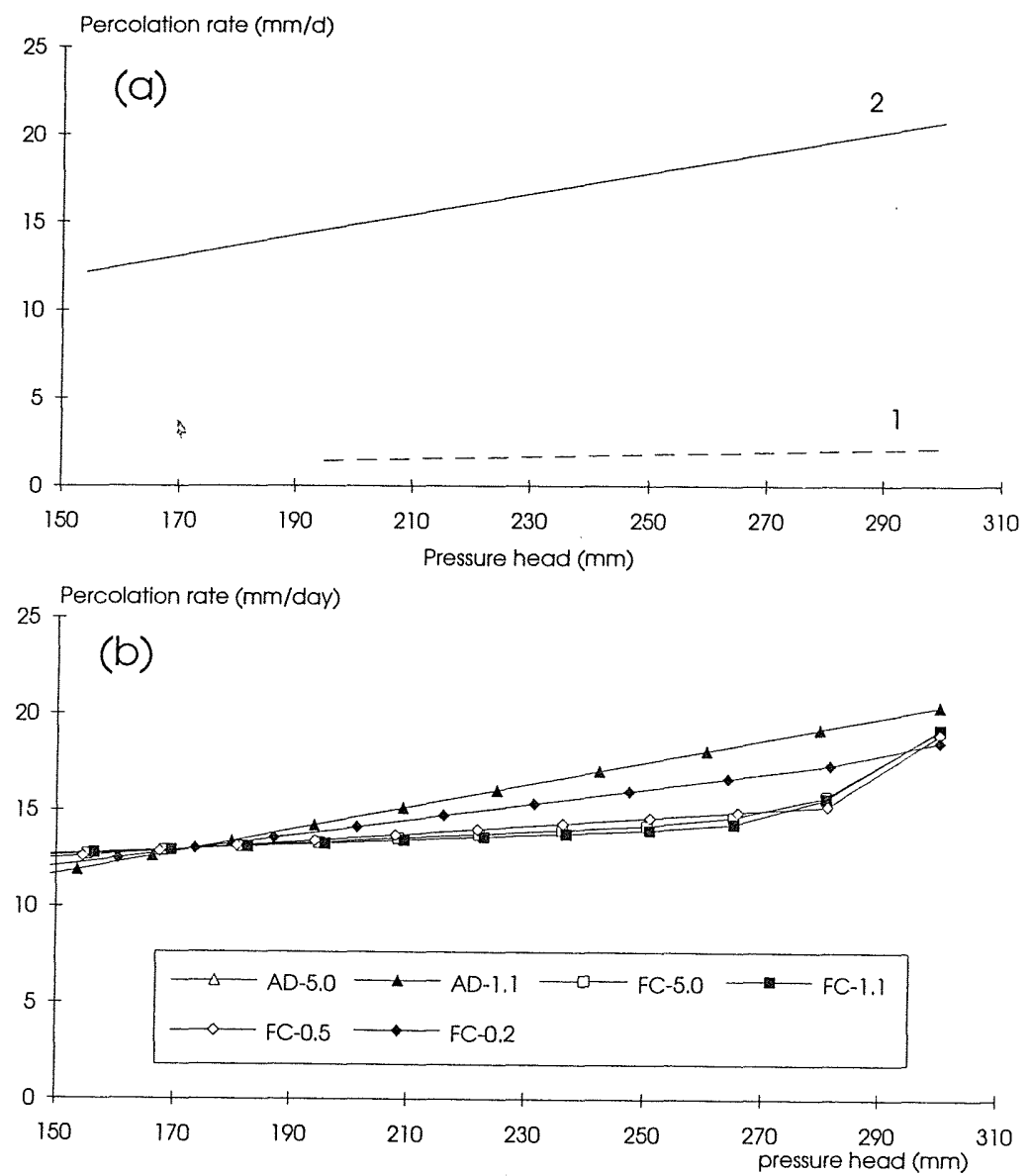

Fig. 5. Steady state percolation rate versus pressure head $h_{\mathrm{lop}}$ at the top of the plow sole. In (a), a poorly permeable plow sole $\left(k_{\mathrm{s}, \text { top }}=0.03 \mathrm{~cm} \cdot \mathrm{d}^{-1}\right)$ is overlaying a permeable sandy loam and a poorly permeable silty clay subsoil (line 1) and a relatively permeable plow sole $\left(k_{\mathrm{s}, \text { top }}=0.3 \mathrm{~cm} \cdot \mathrm{d}^{-1}\right)$ is overlaying a permeable sandy loam (line 2 ). In (b), a relatively permeable plow sole is overlaying a relatively poorly permeable silty clay. The legend refers to the initial water content in the subsoil ( $A D=$ air dry, $F \dot{C}=$ field capacity) and to the depth of the ground water table (5.0, 1.1, 0.5 and $0.2 \mathrm{~m}$ depth). Further details are given in the text and in Table 1 (series 4).

hydraulic conductivity $\left(k_{\mathrm{s} \text {,top }}=0.08 \mathrm{~cm} \cdot \mathrm{d}^{-1}\right)$. In stages 3 and 4 , the plow sole was damaged which resulted in an increased field-average hydraulic conductivity. Since the subsoil was very permeable $\left(k_{s, \text { sub }}=7-300 \mathrm{~cm} \mathrm{~d}^{-1}\right)$, stages 1 and 2 represent soil-hydraulic class $\mathrm{Ib}$. Stages 3 and 4 represent soil-hydraulic class IIb. During stages 2 and 3, SP consisted of only percolation because seepage was effectively stopped by plastic sheets in the field. In stages 1 and 4, seepage contributed significantly to total SP. Seepage and percolation rates were determined at the beginning of each of the four stages from sloping-gauge readings: $3.62,0.40,1.46$ and $3.26 \mathrm{~cm} \mathrm{~d}^{-1}$, respectively. Using these fixed SP rates and daily values of $I, P$ and ET, the depth of ponded water was simulated by Eq. (1).

During all four stages, simulated and observed values of ponded water depth were in 


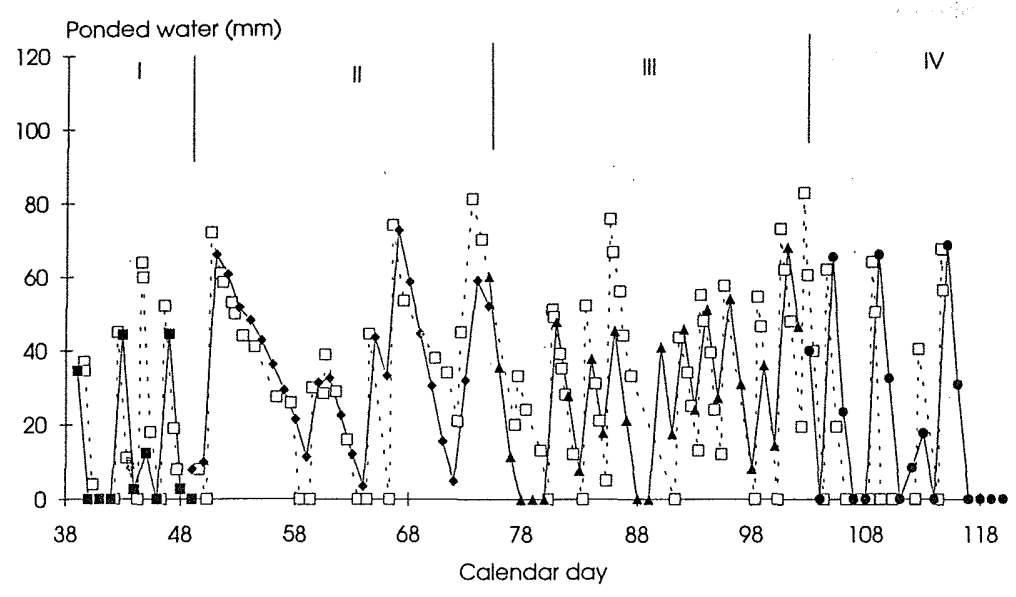

Fig. 6. Observed and simulated ponded water depths by simple book-keeping [Eq. (1)] for the field experiment. The black markers are simulated values; open squares are observed values. The roman letters refer to the four different stages of the experiment (see text).

good agreement (Fig. 6). Some differences occurred because measurements of ponded water were taken on various times of the day, whereas the simulations were done at the start of each day (time steps of one day). The best agreement between measured and simulated ponded water depths was found in stage 2 (soil-hydraulic class Ib) with a low SP rate of $0.4 \mathrm{~cm} \mathrm{~d}^{-1}$. In stages 3 and 4 (soil-hydraulic class IIb), simulated values deviated in some instances significantly $(2-3 \mathrm{~cm})$ from observed values. Given the combination of a high SP rate with a permeable subsoil, the influence of ponded water depth on SP rate may have caused these deviations (see line 2, Fig. 5a).

\section{Summary and discussion}

This paper studied the concept of using constant SP rates in book-keeping of the water balance of paddy fields by first focusing on the effects of soil physical and hydraulic properties, and of hydrologic conditions on percolation rates. Using a detailed soil water balance model, SAWAH, a classification of paddy soils was suggested into four soilhydraulic classes that have similar behaviour in percolation rate:

Ia: poorly permeable plow sole $\left(k_{\mathrm{s}, \mathrm{top}}<10^{-2} \mathrm{~cm} /\right.$ day, $\left.D_{\mathrm{z}}>5 \mathrm{~cm}\right)$ with a poorly permeable subsoil $\left(k_{\mathrm{s}, \text { sub }}<10^{-1} \mathrm{~cm} /\right.$ day $)$

Ib: poorly permeable plow sole with permeable subsoil $\left(k_{\mathrm{s}, \mathrm{sub}}>10^{1} \mathrm{~cm} /\right.$ day $)$

IIa: permeable plow sole $\left(\mathrm{k}_{\mathrm{s}, \text { top }}>10^{-1} \mathrm{~cm} /\right.$ day, $\left.D_{\mathrm{z}}<5 \mathrm{~cm}\right)$ with poorly permeable subsoil; and

IIb: permeable plow sole with permeable subsoil.

Percolation rates in class I are $0-0.5 \mathrm{~cm} \mathrm{~d}^{-1}$. They are limited by the plow sole and are relatively insensitive to ponded water depth and to hydraulic characteristics of the subsoil. 
In class IIa, percolation losses are typically $1-1.5 \mathrm{~cm} \cdot \mathrm{d}^{-1}$ and are limited by the hydraulic characteristics of the (poorly permeable) subsurface. In practice, the water content of the subsurface is often brought at field capacity during land preparation and the percolation rate is at steady state from puddling onward. Percolation losses are relatively insensitive to ponded water depth. In class IIb, high percolation rates of $1-5 \mathrm{~cm} \cdot \mathrm{d}^{-1}$ (and higher) are governed by the hydraulic characteristics of the plow sole and by the depth of ponded water. In this situation, field water losses can be considerably reduced by maintaining a low (close to zero) level of ponded water. This finding is in agreement with empirical results of Ferguson (1970), Sanchez (1973) and Tabal et al. (1992). In classes I and IIa, percolation rates are mainly determined by soil-hydraulic characteristics and are hardly affected by hydrological conditions (soil water content, ground water table depth, ponded water depth). When soil-hydraulic characteristics are stable in time, a constant percolation rate can be used in simple book-keeping of the water balance.

The concept of a constant SP rate including the seepage component was studied on a field experiment with different stages of hydrologic conditions: stages 1 and 2 and stages 3 and 4 had a relatively impermeable (soil-hydraulic class Ib) and permeable plow sole (class $\mathrm{IIb}$ ) respectively over a permeable subsoil; in stages 2 and 3 only percolation occurred, whereas in stages 1 and 4, seepage through and underneath bunds was also present. Simple book-keeping using a constant field-average SP rate predicted measured ponded water depths accurately in soil-hydraulic class Ib with only percolation, stage 2 , and with both seepage and percolation, stage 1 . The predictions with the book-keeping method were as accurate as the simulations with SAWAH using measured (effective) hydraulic conductivities (Fig. 4b, Part I of this paper). However, for practical applications in e.g. irrigation system design and management, detailed models such as SAWAH will be less suitable because of the large data requirements, and because it does not account for seepage. In soilhydraulic class IIb, predicted water depths with the book-keeping method were still in good agreement with measurements, although the predictions were less accurate than for class Ib. The discrepancy between predicted and measured ponded water depths was caused by the effect of ponded water depth in the field and of the differences in water head at either side of the bunds (plastic sheets) on the SP rate. It is expected that the results obtained in this experiment also apply for soil-hydraulic classes Ia and IIa (poorly permeable subsoil). The low permeability of the subsoil will restrict percolation and most seepage flow underneath bunds, thereby limiting seepage losses to horizontal water flow through the bunds themselves (see below).

The soil-hydraulic classes suggested in this paper may form the basis for a decision-tree to estimate the magnitude and variation of SP rates in field situations, and to decide if modelling, whether simple book-keeping or detailed physical modelling, is an appropriate tool to monitor the water balance. Pedo-transfer functions are needed to link the soilhydraulic classes to readily available soil data and/or simple field observations. At several national agricultural research centres in Asia and at IRRI, efforts are currently underway to establish a database linking soil-hydraulic properties to soil horizon descriptions and to easy measurable characteristics like texture, bulk density and organic matter content. Beside hydraulic properties of the soil, other field characteristics should be included in the decisiontree, e.g. those factors that affect seepage through and underneath bunds. Wickham and Singh (1978) reported the importance of the state of maintenance and hydraulic properties 
of bunds (or other side-embankments), and the ratio of total bund length over surface area of the field. In soil-hydraulic classes Ia and IIa (poorly permeable subsoil), seepage flow will be small with impermeable, well-maintained bunds. With ill-maintained, permeable bunds, seepage underneath the bunds is still restricted by the low permeability of the subsoil, but seepage through the bunds may be considerable. In these situations, the concept of a constant SP rate may not be applicable when large variations in the water head differences on either side of the bund occur. In soil-hydraulic class Ib with well-maintained, impermeable bunds, seepage flows are again small. However, when bunds are ill-maintained, water may not only flow horizontally through the bunds, but also percolate vertically through the permeable subsoil underneath the bunds (Tuong et al., 1994). In soil-hydraulic class $\mathrm{IIb}$, seepage as well as percolation rates are high and SP rates will not be constant in time. Seepage flow may occur either underneath well-maintained bunds or through and underneath ill-maintained bunds.

Finally, care should be taken in the application of (simple or detailed) water balance modelling when soil-hydraulic and bund properties change in time. For example, management practices such as weeding, or the drying-out of the puddled layer can affect the hydraulic conductivity of the plow sole, and thereby change the SP rate (Wickham and Singh, 1978; Wopereis et al., 1994a). Lowering of water levels in adjoining fields, drains or ditches may also induce seepage through and underneath bunds where it was previously not present. Fortunately, such actions generally occur at the end of the growing season when keeping track of the water balance becomes less important.

\section{Acknowledgements}

We wish to thank M. Calibo and L. Tatad for assistance with field work. This study was financed by the Netherlands' Ministry for Development Cooperation, project 'Simulation and Systems Analysis for Rice Production"' (SARP).

\section{References}

Angus, J.F. and Zandstra, H.G., 1980. Climatic factors and the modelling of rice growth and yield. In: Agrometeorology of the Rice Crop, IRRI, Los Banos, Philippines, pp. 189-199.

Belmans, C., Wesseling, J.G. and Feddes, R.A., 1983. Simulation models of the water balance of a cropped soil: SWATRE. J. Hydrol., 63: 271-286.

Blaney, H.F. and Criddle, W.D., 1950. Determining water requirements in irrigated areas from climatological and irrigation data. USDA(SCS)TP-96, 48 pp.

Driessen, P.M., 1986. The water balance of the soil. In: H. van Keulen and J. Wolff (Editors), Modelling of Agricultural Production: Weather, Soils and Crops. Simulation Monographs, Pudoc, Wageningen, The Netherlands, pp. 76-116.

FAO, 1984. Crop water requirements. FAO irrigation and drainage paper 24, FAO, Rome, Italy, $144 \mathrm{pp}$.

Ferguson, J.A., 1970. Effect of flooding depth on rice yield and water balance. Arkansas Farm Res., $19: 4$.

Kampen, J., 1970. Water losses and water balance studies in lowland rice irrigation. Ph.D. Thesis, Cornell University, USA, $416 \mathrm{pp}$.

Penman, H.L., 1948. Natural evaporation from open water, bare soil and grass. Proc. R. Soc. London, Ser. A, 193; $120-146$. 
Penning de Vries, F.W.T., Jansen, D.M., ten Berge, H.F.M. and Bakema, A., 1989. Simulation of ecophysiological processes of growth in several annual crops. Simulation Monographs 29. IRRI, Los Baños/Pudoc, Wageningen, The Netherlands, $271 \mathrm{pp}$.

Sanchez, P.A., 1973. Puddling tropical rice soils. 2. Effects of water losses. Soil Sci., 115: 303-308.

Tabal, D.F., Lampayan, R.M. and Bhuiyan, S.I., 1992. Water-efficient irrigation techniques for rice. In: V.V.N. Murty and K. Koga (Editors), Soil and Water Engineering for Paddy Field Management. Proceedings of the International Workshop on Soil and Water Engineering for Paddy Field Management, Asian Institute of Technology, Bangkok, 28-30 January, 1992.

Ten Berge, H.F.M., Jansen, D.M., Rappoldt, K. and Stol, W., 1992. The soil water balance module SAWAH: user's guide and outline. CABO-TPE Simulation Report Series, no. 22. CABO, Wageningen, The Netherlands. 78 pages + appendices.

Tuong, T.P., Wopereis,M.C.S., Marquez, J. and Kropff, M.J., 1994. Mechanisms and control of percolation losses in puddled rice fields. Soil Science Society of America Journal (in press).

Wickham, T.H. and Singh, V.P., 1978. Water movement through wet soils. In: Soils and rice. International Rice Research Institute, Los Banos, The Philippines; pp. 337-357.

Wopereis, M.C.S., Wösten, J.H.M., Bouma J. and Woodhead, T. (1992. Hydraulic resistance in puddled rice soils: measurement and effects on water movement. Soil and Tillage Research 24: 199-209.

Wopereis, M.C.S., Bouma, J., Kropff, M.J. and Sanidad, W., 1994a. Reducing bypass flow through a dry and cracked previously puddled rice soil. Soil and Tillage Research 29: 1-11.

Wopereis, M.C.S., Bouman, B.A.M., Kropff, M.J., ten Berge, H.F.M., and Maligaya, A.R., 1994b. Understanding the water use efficiency of flooded rice fields. I. Validation of the soil-water balance model SAWAH. Agric. Water Manage. (this issue). 